\title{
A DECISION SUPPORT MODEL TO DETERMINE THE CRITICAL SUCCESS FACTORS OF ASSET MANAGEMENT SERVICES
}

\author{
J.L. Jooste ${ }^{1 *} \&$ P.J. Vlok ${ }^{2}$ \\ Asset Care Research Group (ACRG) \\ Department of Industrial Engineering \\ University of Stellenbosch, South Africa \\ ${ }^{1}$ wyhan@sun.ac.za, ${ }^{2}$ pjvlok@sun.ac.za
}

\begin{abstract}
Business-to-business services relating to physical asset management play an increasingly important role in industry. This is in the context of the current pressures that organisations experience in realising optimal value from their assets. Complying with asset management standards such as ISO 55000 contributes towards the importance of these services. This paper summarises the findings from a study identifying the critical success factors for asset management services, and presents a decision support model that provides the asset management community with access to these factors for decision-making and for improving asset management services.
\end{abstract}

\section{OPSOMMING}

Besigheid-tot-besigheidsdienste met betrekking tot fisiese batebestuur speel 'n toenemende belangrike rol in die industrie. Dit is te midde van die druk wat batebesittende organisasies tans ondervind om optimale waarde uit hul fisiese bates te verkry. Die strewe om te voldoen aan batebestuurstandaarde soos ISO 55000 dra by tot die belangrikheid van hierdie dienste. Die verhandeling gee 'n opsomming van 'n studie rakende die identifisering van die kritiese suksesfaktore vir batebestuurdienste, en lê 'n besluitnemingsmodel voor wat die batebestuurgemeenskap toegang gee tot hierdie suksesfaktore vir besluitnemingsdoeleindes en vir die verbetering van batebestuurdienste. 
Business is on the verge of a new wave in asset productivity improvement that will be more difficult to achieve than with past initiatives. The challenge for organisations is the necessity of maintaining, and often increasing, operational effectiveness, revenue, and customer satisfaction, while at the same time reducing capital, operating, and support costs [13]. The effective management of physical assets in support of these pressures is increasingly important to ensure that business goals are obtained. Asset management is defined by the International Organisation for Standardisation (ISO) 55001 [10] as:

"the coordinated activity of an organisation to realise value from assets (where realisation of value involves the balancing of costs, risks, opportunities and performance benefits)."

The potential benefits of asset management are evident from an Aberdeen Group research report, which compares the performance gains from asset management in high and low asset management performing organisations [15]. The top 20 per cent of performers in asset management measure 3.5 per cent in unscheduled asset downtime, 89 per cent on overall equipment effectiveness (OEE), gains of 24 per cent on return on assets (ROA), and a reduction of 13 per cent in maintenance costs. In comparison, organisations that lag behind in asset management measure 16.9 per cent in unscheduled asset downtime, 69 per cent on overall equipment effectiveness (OEE), losses of 24 per cent on return on assets (ROA), and a 1 per cent increase in maintenance costs.

Parallel to asset management, the management literature is unanimous in advocating the integration of services into core product offerings. Historically, most of the value of a product was added from the production process that transformed raw material into a useful product. Today, value comes from technological improvement, styling, branding, and other attributes that only services can create [6, 17, 23]. Grönroos [7] defines services in general using three characteristics:

1. Services are processes consisting of activities or a series of activities.

2. Services are, to some extent at least, produced and consumed simultaneously.

3. The client participates, at least to some extent, as a co-producer in the service production process.

The importance of services is reflected in a World Economic Forum report that states that over 70 per cent of the 137 listed countries have service sectors that contribute more than 50 per cent of their respective gross domestic product (GDP). In South Africa, services represent 66 per cent of the GDP [19].

'Servitisation' is the term used for offering integrated packages of client-focused products, services, support, self-service, and knowledge [20]. Although servitisation occurs in most industries, previous research has mostly focused on the manufacturing and capital goods industries [2]. Research into the services of other industries is sparse. The services literature in the capital goods industry reveals close similarities between capital goods services and asset management activities [8, 14, 22]. Traditionally, services in the field of asset management were limited to transaction-based activities orientated towards the asset. Industry and technological changes are leading to more opportunities for relationship-based and asset management process-orientated services in the field of asset management. These changes are:

- $\quad$ The shift from maintenance management to whole life cycle asset management [1];

- The formalisation and industry acceptance of ISO 55000 (and its predecessor PAS 55) as an asset management standard;

- The shift from off-the-shelf software to software-as-a-service (SaaS) in the enterprise software industry [5]; 
- $\quad$ Enterprise resource planning (ERP) vendors and service providers expanding their software with computerised maintenance management system (CMMS) and enterprise asset management system (EAMS) offerings [9].

With these industrial, technological, and economic pressures, service providers and asset owners are partnering (or collaborating) to manage the asset owner's assets more effectively, and to comply with asset management standards. It is therefore important to understand the underlying factors that are critical to the success of asset management service collaboration and partnerships. These so-called critical success factors (CSF) need to be identified for decision-making purposes to support the sustaining of successful asset management services.

The CSF approach can be used to gain an improved understanding of these factors. The Oxford English Dictionary defines success as "the accomplishment of an aim or purpose", while Leidecker and Bruno [12] define CSF as:

"those characteristics, conditions or variables that, when properly sustained, maintained, or managed, can have a significant impact on the success of an organisation competing in a particular industry."

In the context of the importance of asset management's role in industry, the asset owner's tendency to employ asset management services to overcome industry pressures, and the potential value to be gained from successful asset management service partnerships, the problem is that there is little or no evidence about the CSF for asset management services.

To address the problem, research was initially conducted by Jooste and Vlok [11] to identify the CSF that are required to collaborate in a successful asset management service environment; and then to develop a decision support model to make the CSF available to the asset management service industry for decision-making purposes.

This paper begins with a summary of the findings from the research conducted by Jooste and Vlok [11] on identifying the CSF for asset management services. A description of a decision support model for asset management services follows, and this is used to provide the industry with access to the identified CSF for decision-making purposes and to improve asset management services. The paper concludes with a case study illustrating the use of the model in practice.

\section{A SUMMARY OF THE SUCCESS FACTORS FOR ASSET MANAGEMENT SERVICES}

To identify the success factors for asset management services, Jooste and Vlok [11] used a mixed method design approach for their research. The content of the existing literature was analysed and developed into a Delphi study that resulted in 46 success factors specific to asset management. A survey questionnaire was used to identify the relative importance of each of these factors on a 7-point Likert-type scale. Figure 1 shows four distributions for the sample of 254 respondents who participated in the survey.

In the research, the success factors are grouped into six categories (Table 1) that correspond with the service life cycle phases that contribute to the phases' success. The 46 success factors for asset management services are presented in Table 2, in order of importance based on their mean ranks. The first digit of the factor's number corresponds with the phase in Table 1 . Of the factors, the continued and sustained commitment from the asset owner's senior management $(2 a)$ and open and effective communication between the asset owner and service provider $(5 f)$ were found to be significantly more important than the other success factors (based on t-test comparisons with $a=5 \%$ ). For the remaining 44 factors, no significant differences between adjacent ranked factors were found. This suggests that all 46 success factors contribute to the success of an asset management service during various phases of the service's life cycle. 


\section{Participant Role}
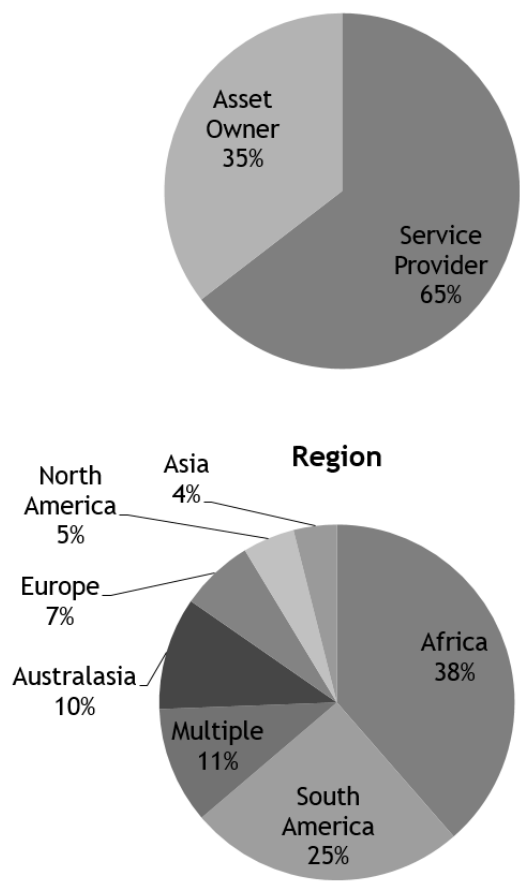

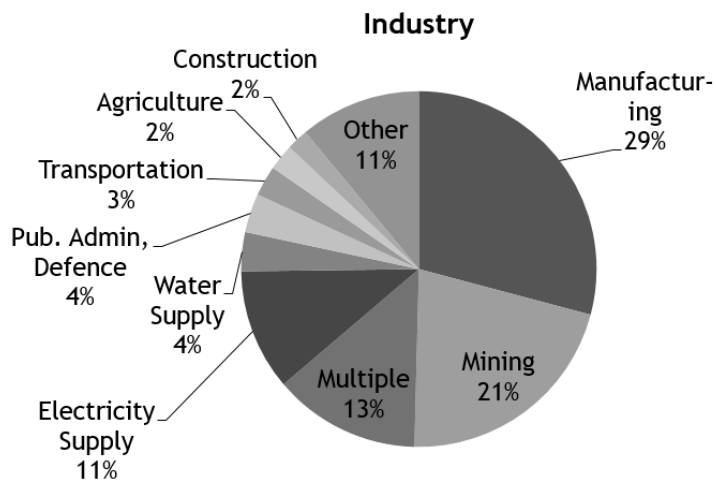

Organisational Level

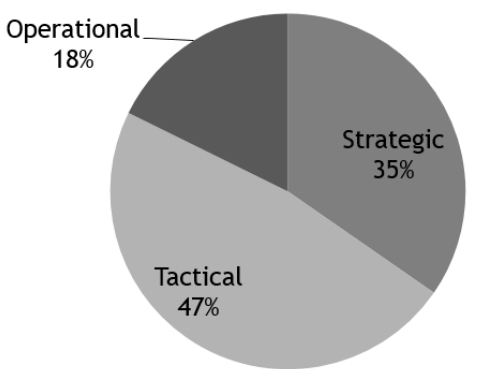

Figure 1: Characteristics of the sample distribution

Jooste and Vlok [11] report that the success factors are universal, and are unaffected by the type of asset management service, the asset management environment, or the type of industry. There are various perspectives on how different role players experience success factors; but the overall effect of these differences - especially for the top 30 per cent of success factors - is negligible, and should not adversely affect the universal use of the success factors across all types of asset management services.

Table 1: Success factor categories corresponding to the service life cycle phases

\begin{tabular}{|c|l|l|}
\hline Phase & Category & Service life cycle phase \\
\hline 1 & Organisational environment and capabilities & - \\
\hline 2 & Initiation phase and pre-contract activities & Value proposition phase \\
\hline 3 & Preparation and design processes & Systems integration phase \\
\hline 4 & Implementation and commissioning activities & Systems integration phase \\
\hline 5 & Control processes & Operational services phase \\
\hline 6 & Benefits and value-add & Operational services phase \\
\hline
\end{tabular}

Table 2: Ranked list of success factors for asset management services

\begin{tabular}{|c|c|c|c|c|}
\hline No. & Mean & $\begin{array}{l}\text { Std. } \\
\text { Dev }\end{array}$ & $\begin{array}{l}\text { Mean } \\
\text { Rank }\end{array}$ & Success Factor Description \\
\hline $2 a$ & 6.413 & 0.897 & 1 & $\begin{array}{l}\text { The continued and sustained commitment from the asset-owning } \\
\text { organisation's senior management in support of the asset } \\
\text { management service. }\end{array}$ \\
\hline $5 f$ & 6.323 & 0.861 & 2 & Open and effective communication. \\
\hline $6 f$ & 6.181 & 0.884 & 3 & $\begin{array}{l}\text { A focused and continuous improvement process to improve the } \\
\text { asset management service through monitoring, analysis, and } \\
\text { feedback. }\end{array}$ \\
\hline $5 g$ & 6.157 & 0.997 & 4 & $\begin{array}{l}\text { Mutual trust and respect between the service provider and client } \\
\text { organisation. }\end{array}$ \\
\hline $2 c$ & 6.15 & 0.946 & 5 & $\begin{array}{l}\text { The alignment of the asset-owning organisation's asset } \\
\text { management service requirements with its overall organisational } \\
\text { and business strategies. }\end{array}$ \\
\hline
\end{tabular}




\begin{tabular}{|c|c|c|c|c|}
\hline No. & Mean & $\begin{array}{l}\text { Std. } \\
\text { Dev }\end{array}$ & $\begin{array}{l}\text { Mean } \\
\text { Rank }\end{array}$ & Success Factor Description \\
\hline $4 a$ & 6.134 & 0.906 & 6 & $\begin{array}{l}\text { An adequate training programme in place for all asset } \\
\text { management service role players, in both the service provider } \\
\text { and the client teams. }\end{array}$ \\
\hline $4 b$ & 6.134 & 1.013 & 6 & $\begin{array}{l}\text { An effective organisational change management programme in } \\
\text { support of the asset management service. }\end{array}$ \\
\hline $6 d$ & 6.122 & 1 & 8 & $\begin{array}{l}\text { Proof of operational and financial performance achievements as } \\
\text { a result of the asset management service. }\end{array}$ \\
\hline $5 j$ & 6.118 & 0.912 & 9 & $\begin{array}{l}\text { The use of performance measurements to monitor, control, and } \\
\text { improve the asset management service. }\end{array}$ \\
\hline $1 f$ & 6.11 & 0.98 & 10 & $\begin{array}{l}\text { The integrity of the leadership and delivery team of the service } \\
\text { provider and the set of values to ensure sustainability of the } \\
\text { service. }\end{array}$ \\
\hline $3 n$ & 6.087 & 0.958 & 11 & $\begin{array}{l}\text { The involvement of knowledgeable and demanding individuals } \\
\text { from the asset-owning organisation during design and } \\
\text { preparation, rather than individuals who prefer to abdicate their } \\
\text { asset management responsibilities. }\end{array}$ \\
\hline $5 \mathrm{~h}$ & 6.067 & 0.953 & 12 & $\begin{array}{l}\text { Active client participation in reporting, problem-solving, and } \\
\text { improvement relating to the asset management service. }\end{array}$ \\
\hline $6 e$ & 6.059 & 0.937 & 13 & $\begin{array}{l}\text { The ability to measure the asset management service quality and } \\
\text { value creation. }\end{array}$ \\
\hline $5 d$ & 5.984 & 0.978 & 14 & $\begin{array}{l}\text { The active management of the relationship between the service } \\
\text { provider and the client organisation personnel involved in the } \\
\text { asset management service. }\end{array}$ \\
\hline $2 f$ & 5.98 & 1.019 & 15 & $\begin{array}{l}\text { The cultural readiness of the asset-owning organisation to } \\
\text { change its business model for delivering asset management } \\
\text { (having the right skills in the organisation to manage a } \\
\text { commercial asset management service partnership, instead of } \\
\text { only the daily management of asset management). }\end{array}$ \\
\hline $1 c$ & 5.969 & 0.945 & 16 & $\begin{array}{l}\text { The technical knowledge, expertise, and capabilities of the } \\
\text { service provider's client-facing team and consultants. }\end{array}$ \\
\hline $2 b$ & 5.965 & 1.083 & 17 & $\begin{array}{l}\text { The active participation of the asset-owning organisation } \\
\text { personnel and their commitment to completing the pre-contract } \\
\text { activities. }\end{array}$ \\
\hline $5 c$ & 5.957 & 0.991 & 18 & $\begin{array}{l}\text { The management of mutual expectations between the service } \\
\text { provider and client relating to the asset management service. }\end{array}$ \\
\hline $1 \mathrm{a}$ & 5.953 & 1.099 & 19 & $\begin{array}{l}\text { A capable project (or key account) manager who manages the } \\
\text { asset management service on behalf of the service provider. }\end{array}$ \\
\hline $5 \mathrm{k}$ & 5.921 & 0.933 & 20 & $\begin{array}{l}\text { Proper priority setting of improvement actions, irrespective of } \\
\text { whether it is service or value-add related. }\end{array}$ \\
\hline $6 b$ & 5.902 & 0.995 & 21 & $\begin{array}{l}\text { Feedback and sharing of lessons learned from successful } \\
\text { improvements made to the asset management service. }\end{array}$ \\
\hline $5 i$ & 5.878 & 0.98 & 22 & $\begin{array}{l}\text { Agility (responsiveness) in responding to changes in asset } \\
\text { management service demands. }\end{array}$ \\
\hline $1 d$ & 5.87 & 0.942 & 23 & $\begin{array}{l}\text { The availability of the most appropriate skilled resources to } \\
\text { provide industry-specific asset management service } \\
\text { requirements. }\end{array}$ \\
\hline $3 m$ & 5.862 & 0.994 & 24 & $\begin{array}{l}\text { The ability to design a practical solution for the asset-owning } \\
\text { organisation's existing asset management maturity; but also to } \\
\text { consider (in the design) the long term goals for the asset } \\
\text { management maturity targets. }\end{array}$ \\
\hline $3 \mathrm{j}$ & 5.858 & 1.027 & 25 & $\begin{array}{l}\text { The availability of adequate information system infrastructure } \\
\text { and interfaces in support of the asset management service. }\end{array}$ \\
\hline $5 a$ & 5.839 & 0.979 & 26 & $\begin{array}{l}\text { The monitoring of budgets and costs relating to the asset } \\
\text { management service. }\end{array}$ \\
\hline $1 e$ & 5.831 & 1.048 & 27 & $\begin{array}{l}\text { The service provider team's internal characteristics (e.g. service } \\
\text { continuity when team members are redeployed to other } \\
\text { services, and handover between service phases, such as } \\
\text { implementation to operations). }\end{array}$ \\
\hline $2 \mathrm{e}$ & 5.827 & 1.136 & 28 & A detailed project plan with milestones in place. \\
\hline $3 \mathrm{~h}$ & 5.791 & 1.257 & 29 & $\begin{array}{l}\text { The integration of health, safety, environmental, and quality } \\
\text { considerations as part of the asset management service, or to } \\
\text { align the service to existing standards. }\end{array}$ \\
\hline
\end{tabular}




\begin{tabular}{|c|c|c|c|c|}
\hline No. & Mean & $\begin{array}{l}\text { Std. } \\
\text { Dev }\end{array}$ & $\begin{array}{l}\text { Mean } \\
\text { Rank }\end{array}$ & Success Factor Description \\
\hline $3 b$ & 5.776 & 1.018 & 30 & $\begin{array}{l}\text { The inter-company flow of information between the service } \\
\text { provider and the asset-owning organisation during the asset } \\
\text { management service design. }\end{array}$ \\
\hline $2 g$ & 5.752 & 1.055 & 31 & $\begin{array}{l}\text { The service provider's belief that it will deliver benefits by } \\
\text { overcoming obstacles that are unknown at this stage of the } \\
\text { process, and that the collaboration will result in positive } \\
\text { benefits for the individuals and the organisation. }\end{array}$ \\
\hline $1 b$ & 5.72 & 1.109 & 32 & $\begin{array}{l}\text { The degree to which the service provider's client-facing team is } \\
\text { knowledgeable about the full range of the service provider's } \\
\text { value propositions and the available combination of service } \\
\text { options. }\end{array}$ \\
\hline $3 a$ & 5.713 & 1.045 & 33 & $\begin{array}{l}\text { The design and integration of service and performance metrics } \\
\text { for all stakeholders (service provider and asset owner) involved } \\
\text { in the asset management service. }\end{array}$ \\
\hline $6 a$ & 5.673 & 1.092 & 34 & $\begin{array}{l}\text { The consideration of intangible (not measurable) benefits and } \\
\text { value creation (e.g. increased effectiveness, risk mitigation, } \\
\text { improved decision-making capability) as a result of the asset } \\
\text { management service. }\end{array}$ \\
\hline $6 c$ & 5.646 & 1.153 & 35 & $\begin{array}{l}\text { Formal post-launch evaluations of the asset management service } \\
\text { to determine what can be improved. }\end{array}$ \\
\hline $3 f$ & 5.524 & 1.172 & 36 & $\begin{array}{l}\text { The strategic fit of the asset management service with the } \\
\text { service provider and the asset-owning organisation's current } \\
\text { service propositions, systems, and capabilities. }\end{array}$ \\
\hline $5 b$ & 5.504 & 1.032 & 37 & $\begin{array}{l}\text { The configuration control of current asset management service } \\
\text { processes and systems. }\end{array}$ \\
\hline $3 i$ & 5.5 & 1.362 & 38 & $\begin{array}{l}\text { The integration of operational excellence methodologies such as } \\
\text { TPM, TQM, and } 5 S \text { into the asset management service offering, } \\
\text { or to align the service to existing standards. }\end{array}$ \\
\hline $3 \mathrm{k}$ & 5.402 & 1.218 & 39 & $\begin{array}{l}\text { Adequate legacy system knowledge (e.g. ERP) if such systems } \\
\text { are required to interface with the asset management service } \\
\text { information systems. }\end{array}$ \\
\hline $2 d$ & 5.276 & 1.308 & 40 & Compilation and availability of formal contractual documents. \\
\hline $3 d$ & 5.268 & 1.209 & 41 & $\begin{array}{l}\text { Ensuring that pre-project arrangements are made for logistics, } \\
\text { feasibility studies, and changes in organisational structures that } \\
\text { might arise from the asset management service. }\end{array}$ \\
\hline $3 c$ & 5.26 & 1.194 & 42 & The compilation and active use of design documents. \\
\hline 31 & 5.228 & 1.451 & 43 & $\begin{array}{l}\text { The security and protection of information relating to } \\
\text { information systems that form part of the asset management } \\
\text { service. }\end{array}$ \\
\hline $3 e$ & 5.193 & 1.339 & 44 & $\begin{array}{l}\text { The potential of the asset management service to be scalable } \\
\text { (expandable to other business units within the asset-owning } \\
\text { organisation). }\end{array}$ \\
\hline $3 g$ & 5.142 & 1.233 & 45 & $\begin{array}{l}\text { The evaluation and consideration of different asset management } \\
\text { service designs. }\end{array}$ \\
\hline $5 e$ & 5.118 & 1.337 & 46 & $\begin{array}{l}\text { The appreciation of diversity among inter-company teams } \\
\text { involved in the asset management service. }\end{array}$ \\
\hline
\end{tabular}

In summary, Author1 and Author2's [11] research is the first to explore the identification of factors affecting the synergy between asset management and services. The factors in Table 2 should be actively managed during each of the service life cycle phases by all the role players, to make a successful asset management service partnership most likely.

Four underlying themes emerge from the research. First, there needs to be continuous support from the asset owner's management for the asset management service (factors $2 a$, $3 n$ and $5 h$ ). Second, the service needs to be built on sustainable collaboration between the asset owner and the service provider (factors $2 c, 4 a, 4 b, 5 f$ and $5 g$ ). Third, a performance management system needs to be in place that includes a measurement system and process (5f), proof of operational and financial benefits as a result of the asset management service $(6 d)$, and measurement of the service quality and value-add (including, but not limited to operational or financially-orientated benefits) $(6 e)$. Fourth, the improvement of both the 
service relationship and the value creation as a result of the service needs to be actively managed ( $6 f$ and $5 f)$.

\section{THE NEED FOR A DECISION SUPPORT MODEL}

The improvement of a specific asset management service - based on the success factors and the growth of the partnership as a result of the improvement process - is important. Success factors for a specific asset management service could require different prioritisation as a result of an organisation's competitive position, compared with its peers in the industry, based on specific managerial positions, the conditions of the macro environment in which the organisation operates, and temporary success factors becoming critical for certain periods of time [18]. This implies that a single prioritised set of success factors is unsuitable for all asset management service instances. Flexibility is necessary for an asset owner and service provider to select and agree on a set of CSF and on a modus operandi for prioritising and managing the CSF in support of the current dynamics of the asset management service.

The success factors identified in Table 2 serve as a source of overall benchmarking data for the success of asset management services. A mechanism is needed to facilitate the process of agreeing on the specific CSF required for incorporation into the contractual and servicelevel agreement of the asset management service to ensure a high probability of success. A decision support model is an appropriate instrument for this decision-making process.

\section{4 “DSMAMS” - DECISION SUPPORT MODEL FOR ASSET MANAGEMENT SERVICES}

To address this need, the decision support model for asset management services, referred to as 'DSMams' (pronounced "DS-Mams"), is developed to consolidate Author1 and Author2's [11] research on success factors that support the industry in asset management services decision-making. The model aims to give asset owners and service providers access to the research data. This is realised through a structured approach where the role players self-assess their asset management service, compare it with the research data, and use the results to improve the service.

Figure 2 illustrates the main building blocks of the DSMams. Macro-enabled Microsoft Excel with Visual Basic Applications is used to integrate the components. The database consists of the research data from Author1 and Author2's [11] research, which serves as industry benchmarking data. The user interface is in the form of standard Microsoft Excel worksheets and data entry controls. The model components process the inputs, compare them with the benchmarking data, and apply logic to produce the output graphs and tables.

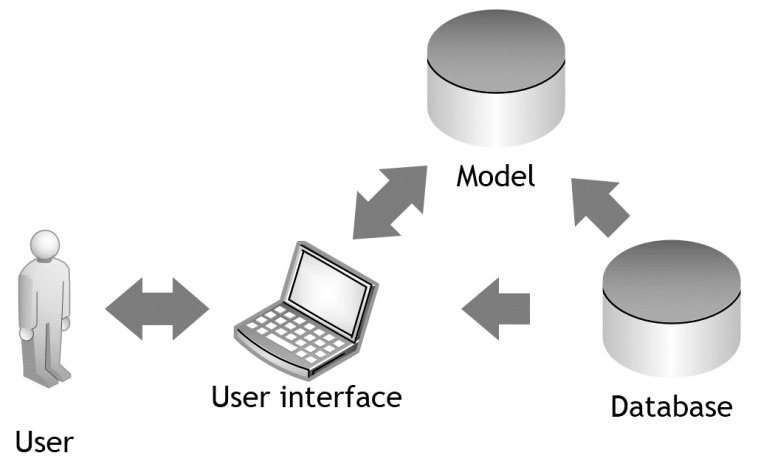

Figure 2: Main building blocks of DSMams

The DSMams is flexible in that it allows users to customise the benchmarking data for their specific asset management service. It incorporates independent self-assessments by the 
asset owner and service provider, along with collaborative reviews of the self-assessment results using an Agreement Matrix chart.

A Prioritised List of CSF gives guidance about the factors on which there should be focus. Follow-up self-assessments and benchmark compliance can be compared with previous assessments to determine whether the plan of action has produced improvements.

The DSMams further supports various decision-making processes. It can be used during the implementation of the asset management service to determine criteria for the contractual or service-level agreement. For existing asset management services, the model is used for governance through service-level agreement reviews, for problem-solving when problems are encountered, and for continuous improvement.

The DSMams architecture is shown in Figure 3. Through the user interface, the DSMams functions are executed in three control sequences to produce the outputs. The model logically draws data from the database, based on the user inputs, and consists of functions that process the data into outputs for decision-making by the users.
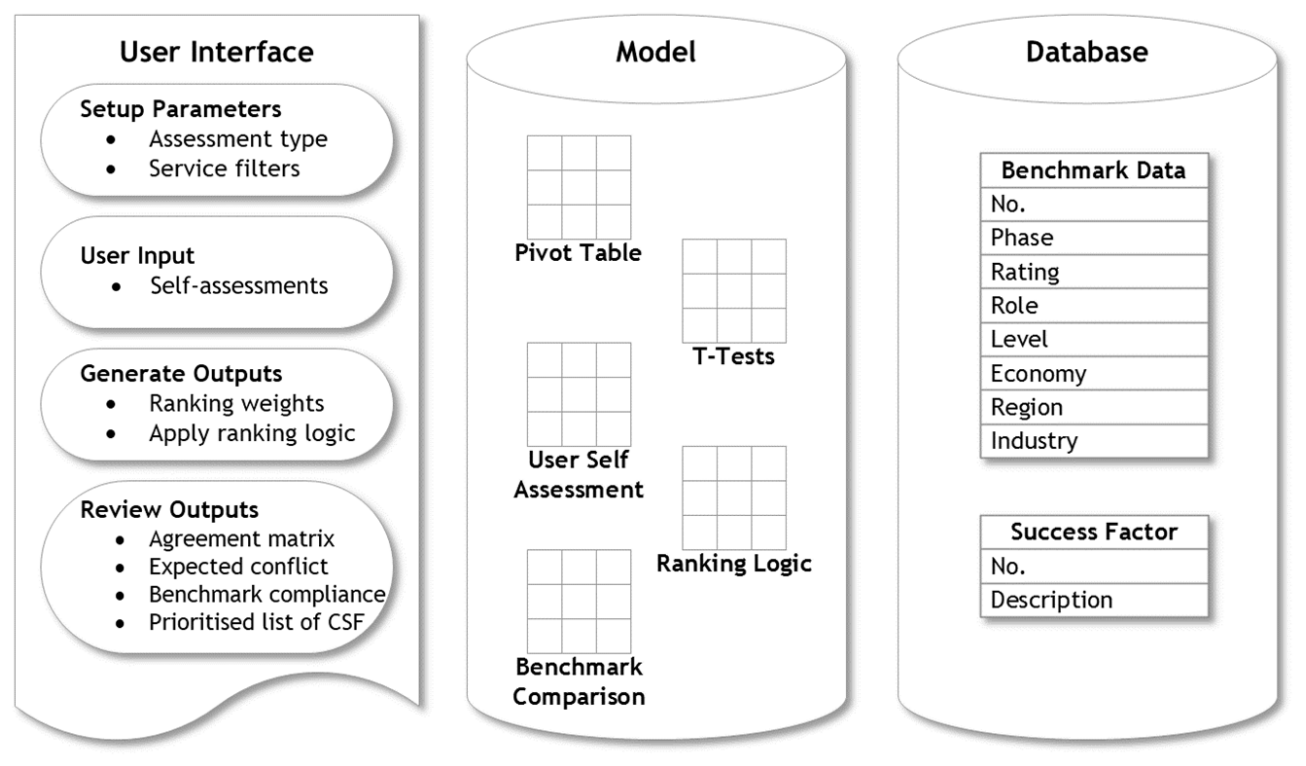

Figure 3: DSMams architecture

\subsection{Setup parameters and pivot table}

The DSMams is initiated by specifying the setup parameters. The user starts by selecting an assessment type and service specific filters (such as the service life cycle phase, industry, geographical region, economy, and organisational level) to determine the number of success factors to be assessed. There are three types of assessments to choose from: full, transitional, and critical; a full assessment includes all 46 success factors in the assessment. A transitional assessment includes the success factors with mean values greater than or equal to the overall benchmarking data mean (5.807); and a critical assessment only includes the top-ranked success factors with means exceeding 6 . As a guideline, the full assessment should be conducted for first-time asset management service implementations; a transitional assessment for the expansion of an asset management service and for problem-solving; while a critical assessment should be conducted for ongoing support and monitoring of the asset management service-level agreement. The setup parameters entered by the user determine the filtering of the model's pivot table for extracting the relevant data from the database for the self-assessment and ranking of the factors. 


\subsection{User input through self-assessment}

A requirement for the user input is that both service provider and asset owner self-assess the asset management service. The two self-assessments include the success factors that correspond to the assessment type and the filter criteria selected, and these are integrated through a look-up function from the pivot table.

In the quality management domain, the principles 'in place' and 'in use' are used to compare an existing system with a standard; this means that a list of requirements is formally implemented ('in place') and actively used or followed ('in use'). For the selfassessment, the two parties independently assess each success factor on a visual analogue scale ranging between 'not in place, being dysfunctional, and requiring improvement' and 'in place, effective or optimal, with no improvement required'. The assessment indicates the extent to which the asset management service adheres to each of the success factors.

\subsection{Generating outputs}

The final control sequence executed by the user is the generation of the model outputs. The user has the option of changing the weights of the ranking variables (see §4.4.2) before applying the ranking logic to generate the outputs. The order in which the user executes the control sequences in the user interface is important. Once the self-assessment starts, the setup parameters cannot be changed without redoing the self-assessment. Changes to self-assessment scoring and ranking weights can be reapplied by generating the outputs again (Figure 4).

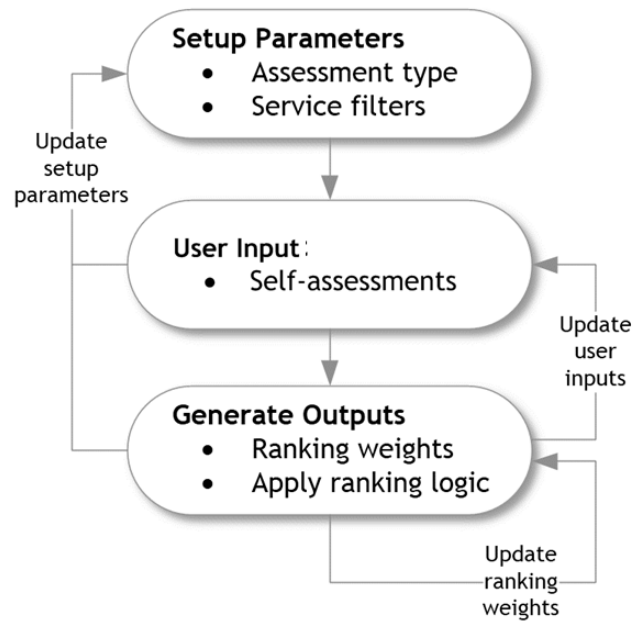

Figure 4: DSMams control sequence order

\subsection{DSMams outputs}

The DSMams produces four outputs to support and facilitate the decision-making process: two graphs, a ranked list of CSF, and an infographic. The two primary outputs are the Agreement Matrix chart and the Prioritised list of CSF. An Expected Conflict chart supports the primary outputs to resolve potentially conflicting perspectives between the service provider and the asset owner. A Benchmark Compliance infographic is used for management control to show compliance of the current service success status with the expected industry benchmarks for similar asset management services.

\subsubsection{Agreement Matrix chart}

The agreement matrix is the visual representation of three ranking variables (see Figure 5 for an example). The variables are combined as overlays in the agreement matrix. It shows the perceptions of adherence to a success factor for both the service provider (on the $x$ axis) and the asset owner (on the $y$-axis). The $x$ and $y$ intersection is represented by a bubble. The bubble sizes correspond with the mean rank of the success factor. The larger the bubble, the higher the benchmark mean is ranked. 
Three diagonal zones correspond to the consensus between the service provider and the asset owner over current adherence to the success factor. It is represented by the function $f(c)=|x-y|$. The central zone represents factors where $|x-y| \leq 25 \%$, or a 25 per cent or less difference in perception of adherence. This is seen as an agreement zone due to the small variation. Factors on the outside danger zones indicate larger differences, where $100 \% \geq|x-y|>25 \%$. These factors imply lower consensus between the two parties, and are ranked higher due to misalignment and the potential problems and conflict that could arise from these differences.

The four contour bands represent levels of adherence. Adherence is represented by the function $f(a)=x y$. The top right zone represents adherence of $75<f(a) \leq 100$, with 100 being the highest level of adherence (i.e. both service provider and asset owner score a maximum score factor of 10 during the self-assessment). The second band represents $50<$ $f(a) \leq 75$, the third $25<f(a) \leq 50$, and the fourth $0<f(a) \leq 25$. The lower the adherence of a factor, the higher it is ranked.

\subsubsection{Prioritised list of CSF}

The prioritised list of CSF forms part of the primary outputs and supports the agreement matrix with a list of CSF, their priorities and descriptions (see Figure 7 as an example). The prioritised list of CSF is based on ranking logic that combines the three weighted ranking variables depicted in the agreement matrix - i.e., the ranks of the industry benchmark means, the consensus between service provider and asset owner over adherence, and the adherence of the service to the industry benchmark (equally weighted as the default).

The choice of ranking variables is based on industry best practices such as benchmarking [3], quality management systems, and the findings from the research of Jooste and Vlok [11] on the identified success factors for asset management services. These variables support asset management service improvement, collaboration, and good governance. The ranks of the factors in the prioritised list of CSF are calculated as:

$R_{i}=W_{B R}\left(B R_{i}\right)+W_{C R}\left(C R_{i}\right)+W_{A R}\left(A R_{i}\right)$,

where for the $i^{\text {th }}$ success factor, $B R_{i}=\operatorname{rank}\left(\bar{z}_{l}\right), \quad C R_{i}=\operatorname{rank}\left(\left|x_{i}-y_{i}\right|\right)$, and $A R_{i}=$ $\operatorname{rank}\left(x_{i} y_{i}\right)$, with $x_{i}$ and $y_{i}$ the respective service provider and asset owner self-assessment scores, $\bar{z}_{l}$ the benchmarking data mean, and $W_{B R}, W_{C R}$, and $W_{A R}$ the respective percentage weighting factors adding up to 100 per cent.

Standard competition ranking is used, where items comparing equally receive the same ranking number, with a gap left in the ranking numbers. Ascending ranks are used, which means that 1 is the highest rank.

\subsubsection{Expected conflict chart}

The expected conflict chart is a secondary output in support of the agreement matrix and the prioritised list of CSF (see Figure 6 as an example). The chart depicts the mean difference as well as the results of the null hypothesis (that is, that the means between the industry benchmarking data for the service providers and the asset owners are equal for a success factor). The mean difference for the $i^{\text {th }}$ success factor is given as:

$d_{i}=\bar{a}_{\iota}-\bar{b}_{l}$,

where $\bar{a}_{l}, \bar{b}_{l}$ are the respective benchmarking means of the asset owner and service provider samples. The mean difference implies that a positive value is associated with a success factor being more important to the asset owner, while a negative value indicates its greater importance to the service provider. The Welch $t$-test is used to test the hypothesis due to the unequal variances between the asset owner and service provider samples [21]: 


$$
t_{i}=\frac{\overline{a_{l}}-\overline{b_{l}}}{\sqrt{\frac{S_{a}^{2}}{N_{a}}+\frac{S_{b}^{2}}{N_{b}}}}
$$

where $S_{a, b}^{2}$ and $N_{a, b}$ are the sample variance and sample size. The degrees of freedom $v$ associated with the variance estimate are approximated as:

$v \approx \frac{\left(\frac{s_{a}^{2}}{N_{a}}+\frac{s_{b}^{2}}{N_{b}}\right)^{2}}{\frac{s_{a}^{4}}{N_{a} v_{i}}+\frac{s_{b}^{4}}{N_{b} v_{i}}}$

where $v_{i}=N_{i}-1$ is the degrees of freedom of the $i^{\text {th }}$ success factor variance estimate. The $p$-value is the probability of obtaining a test statistic value based on the Student $t$ distribution. The $p$-value is tested against $\alpha=5 \%$. For $p \leq \alpha$ there is evidence of a significant difference between the asset owner and the service provider benchmarking mean responses (should any exist).

For some success factors, Jooste and Vlok [11] found that the participant role stratum shows statistically significant differences between service provider and asset owner response means. It is expected that similar differences of opinion may arise during the decision-making process facilitated by DSMams. The expected conflict chart highlights the factors for which the industry benchmarks show large differences, and for which role player the factor is more or less important. The expected conflict chart ensures that potentially conflicting perspectives on factors are made explicit to aid the resolution process.

\subsubsection{Benchmark compliance infographic}

The benchmark compliance infographic shows how the service compares with the industry benchmarking data (see Figure 9 as an example). It overlays compliance percentages for each of the service life cycle phases, and shows a combined compliance for the overall service. The compliance percentage is based on the sum-product of the minimum adherence percentages and benchmark means, expressed as a percentage of the sum of the benchmark data means. Benchmark compliance per service life cycle phase, $B C_{j}$, and for the overall service, $B C_{T}$, are given as:

$B C_{j}=\frac{\sum_{i} \bar{z}_{l}\left(\frac{\left\{x_{i} ; y_{i}\right\}_{\min }}{r_{\max }}\right)}{\sum_{i} \bar{z}_{l}}$,

where $\bar{z}_{l}, x_{i}, y_{i}$ are the respective benchmark mean, service provider, and asset owner selfassessment scores for the $i^{\text {th }}$ success factor in the $j^{\text {th }}$ service life cycle phase, with $r_{\max }=10$ being the maximum allowed self-assessment score.

$B C_{T}=\frac{\sum_{i=1}^{n} \overline{z_{l}}\left(\frac{\left\{x_{i} ; y_{i}\right\}_{\min }}{r_{\max }}\right)}{\sum_{i} \overline{\bar{z}_{l}}}$,

for the $i^{\text {th }}$ to the $n^{\text {th }}$ success factors associated with the selected assessment type.

\section{DSMAMS CASE STUDY}

As part of the validation process of DSMams, a case study is conducted to test the model in practice. The case study results and feedback from the participants are presented as an example of how DSMams can be applied to decision-making in industry. The case study is the asset management service between the City of Cape Town's Electrical Support Services and Pragma, a South African asset management service provider. 


\subsubsection{Case study background}

The Electrical Support Services (ESS) department is responsible for civil projects and maintenance, corrosion protection, electrical projects, and transformer refurbishment for the City of Cape Town's Electricity Directorate.

ESS and Pragma partnered in 2007 in response to the problematic control of work requirements, the associated frustration from internal clients, long work lead times, and the under-utilisation of their SAP Plant Maintenance (SAP PM) system for accessing information. A team of seven Pragma employees work with the ESS team on various asset management activities in the context of the asset management service. These activities include: work planning, monitoring and control, system analysis and optimisation for improving alignment between SAP PM and ESS business requirements, asset management reporting, and root cause and failure analysis [16].

In 2010, ESS won the best client award from Pragma (out of 155 participants across all sectors). For their role as an ISO-accredited organisation, the South African Bureau of Standards (SABS) gave ESS an award for excellence in business growth, productivity, and continuous improvement [4].

The head of ESS (hereafter 'asset owner') and the key account manager of Pragma responsible for the asset management service at ESS (hereafter 'service provider') participated in the case study. Based on the long-standing relationship and the awards received, it is expected that this asset management service should show high levels of adherence to the CSF results produced by the DSMams for this specific type of service.

\subsubsection{Case study results}

For the DSMams setup parameters, a transitional assessment was selected. For the filters, the implementation phases of the service life cycle were excluded, and only the electricity supply industry benchmarking data was included. The initial setup of DSMams resulted in 14 CSF. The self-assessment of the service against the CSF was done via web survey, and the results were transferred to the DSMams. Equal weights for the ranking variables were used.

Figure 5 shows the resulting agreement matrix. The results show that the CSF are highly concentrated in the top right zone, which means that most of the CSF for this asset management service are strongly adhered to and agreed on by both the asset owner and the service provider. Initially, factors $1 a, 1 f, 1 e$ and $1 d$ are the exceptions and show opportunities for improvement.

Figure 6 illustrates the $t$-test results for the corresponding benchmarking data in the expected conflict chart. The chart shows that factors $1 a$ and $1 f$ have the biggest differences between service provider and asset owner perspectives based on the benchmarking data. Factor $1 a$ is more important to service providers, while factor $1 f$ is more important to asset owners. For the selection of CSF for this case study, none of the factors have $p$-values in the critical region, indicating insufficient evidence to reject the null hypothesis that there are significantly different perspectives between the role players on the success factors. Therefore there is no evidence from the benchmarking data to expect conflict between the role players. However, conflict may still surface due to the service dynamics and role player interaction in the service between ESS and Pragma. This needs to be addressed, even if DSMams does not anticipate such differences.

Figure 7 shows the prioritised list of the CSF in support of the agreement matrix. Overall, both the asset owner and the service provider were satisfied that the results represented the current status of their asset management service. Discussion followed on two aspects of the preliminary results. 


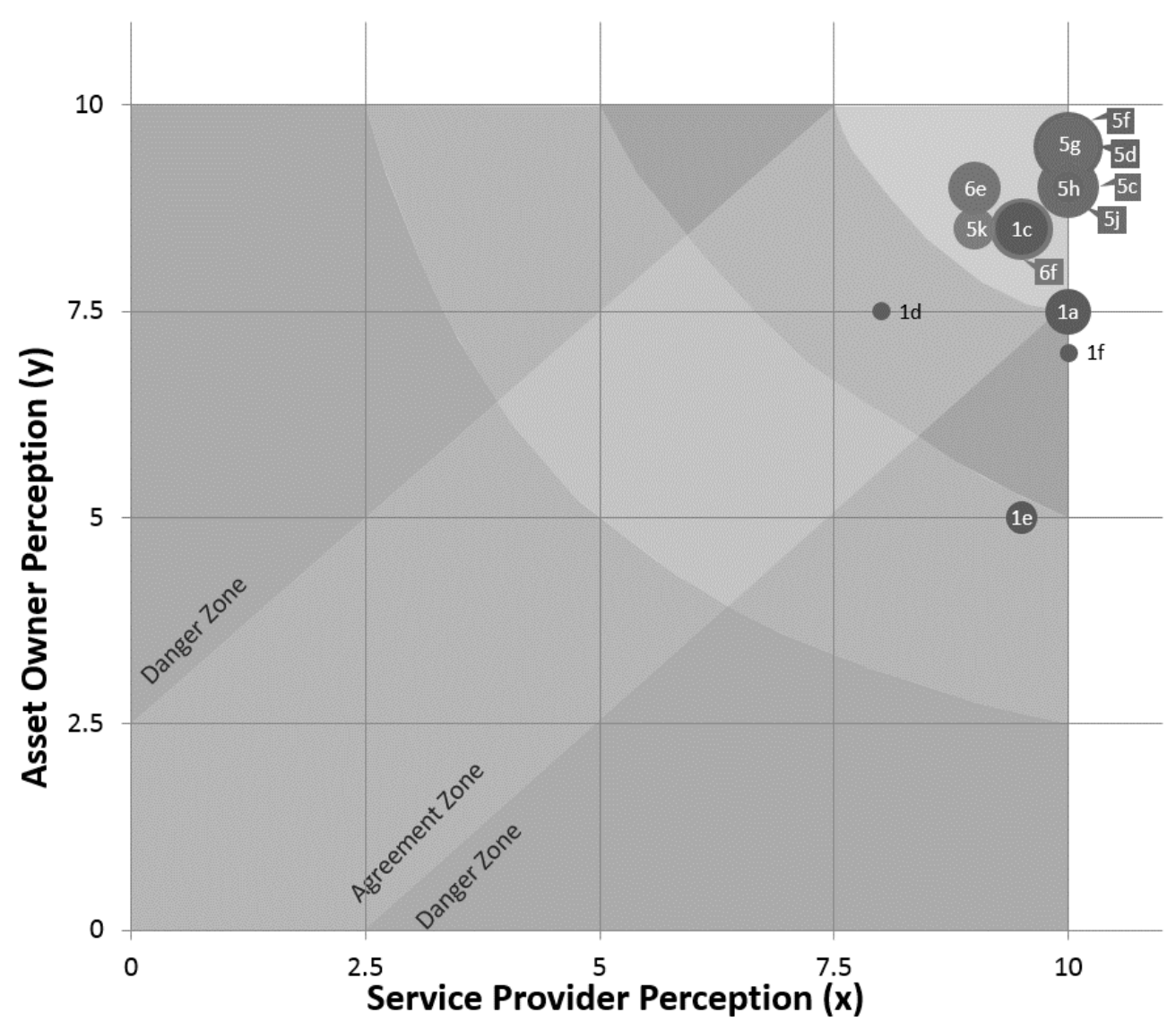

Figure 5: Agreement matrix for the service in the case study

First, the participants expected factors $1 a, 1 f, 1 e$ and $1 d$ to be the higher priority items in the prioritised list of CSF (Figure 7). Factors were ranked as follows: $1 e$ - second, 1a fourth, $1 f$ - sixth, and $1 d$ - tenth. The observation was made that the industry benchmark importance could have an excessive influence due the narrow range of means (5.929 to 6.464) on which the ranks were based. A suggestion was to change the weighting for the industry benchmark ranking variable to 20 per cent and 40 per cent respectively for the consensus and level of adherence ranking variables. This change produced a new prioritised list of CSF. The participants agreed that the lower weight for the benchmark mean compensated for its narrow range of means, and that this was a better representation of the CSF on which they felt they should focus their improvement efforts.

Second, the participants discussed factors $1 a, 1 f$ and $1 e$, which showed the lowest levels of consensus. For all three of the CSF, the asset owner's scores were significantly lower than the service provider's scores. These three CSF related to the service provider's organisational environment and capabilities. On closer investigation, the asset owner indicated that he had misinterpreted the questions on these factors; in the light of this, the self-assessment scoring and the DSMams results were updated. Figure 8 shows the updated prioritised list of CSF reflecting changes to the ranking variable weights and updated asset owner scores. Figure 9 depicts the associated compliance percentages against the benchmarking data for each of the three service life cycle phases included in the case study. 


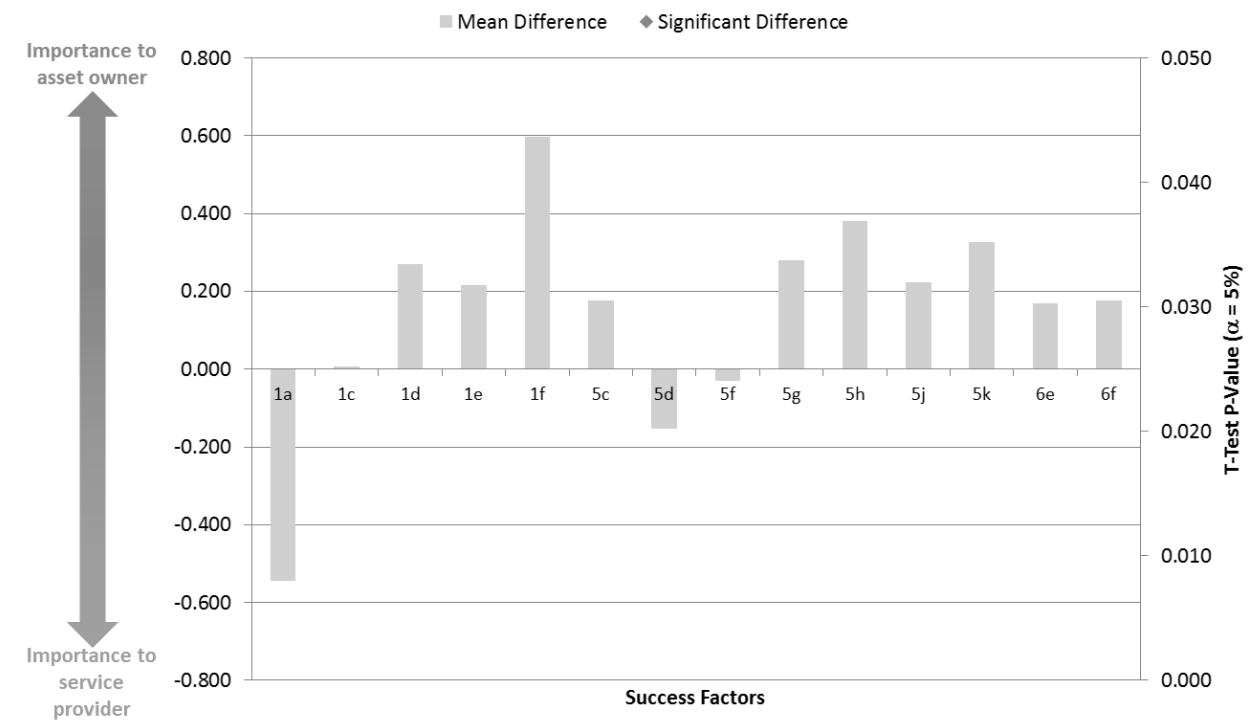

Figure 6: Expected conflict graph for the case study

\begin{tabular}{|c|c|c|c|c|c|c|}
\hline CSF & $\checkmark$ & \begin{tabular}{c|c|} 
Bench- & \\
mark & -
\end{tabular} & $\begin{array}{l}\text { Consen- } \\
\text { sus Dif }-\end{array}$ & \begin{tabular}{r|r|} 
Adherence \\
-
\end{tabular} & $\operatorname{Rank}^{*} \mathbf{T}$ & Description \\
\hline $6 f$ & & 6.214 & 1 & 80.75 & 4.002 & $\begin{array}{l}\text { A focused and continuous improvement process to improve the asset management } \\
\text { service through monitoring, analysis, and feedback. }\end{array}$ \\
\hline $1 \mathrm{e}$ & & 5.964 & 4.5 & 47.5 & 4.33 & $\begin{array}{l}\text { The service provider team's internal characteristics (e.g. service continuity when team members } \\
\text { are redeployed to other services, and handover between service phases, such as implementation } \\
\text { to operations). }\end{array}$ \\
\hline $5 c$ & & 6.214 & 1 & 90 & 5.004 & $\begin{array}{l}\text { The management of mutual expectations between the service provider and client } \\
\text { relating to the asset management service. }\end{array}$ \\
\hline $1 \mathrm{a}$ & & 6.036 & 2.5 & 75 & 5.332 & $\begin{array}{l}\text { A capable project (or key account) manager who manages the asset management } \\
\text { service on behalf of the service provider. }\end{array}$ \\
\hline $1 c$ & & 6.107 & 1 & 80.75 & 5.334 & $\begin{array}{l}\text { The technical knowledge, expertise, and capabilities of the service provider's client- } \\
\text { facing team and consultants. }\end{array}$ \\
\hline $1 f$ & & 5.929 & 3 & 70 & 5.997 & $\begin{array}{l}\text { The integrity of the leadership and delivery team of the service provider and the set } \\
\text { of values to ensure sustainability of the service. }\end{array}$ \\
\hline $5 j$ & & 6.071 & 1 & 90 & 7.002 & $\begin{array}{l}\text { The use of performance measurements to monitor, control, and improve the asset } \\
\text { management service. }\end{array}$ \\
\hline $5 f$ & & 6.464 & 0.5 & 95 & 7.338 & Open and effective communication. \\
\hline $5 d$ & & 6.214 & 0.5 & 95 & 7.671 & $\begin{array}{l}\text { The active management of the relationship between the service provider and the } \\
\text { client organisation personnel involved in the asset management service. }\end{array}$ \\
\hline $1 d$ & & 5.929 & 0.5 & 60 & 7.994 & $\begin{array}{l}\text { The availability of the most appropriate skilled resources to provide industry-specific } \\
\text { asset management service requirements. }\end{array}$ \\
\hline $5 \mathrm{k}$ & & 6.000 & 0.5 & 76.5 & 7.997 & $\begin{array}{l}\text { Proper priority setting of improvement actions, irrespective of whether it is service or } \\
\text { value-add related. }\end{array}$ \\
\hline $5 \mathrm{~h}$ & & 5.964 & 1 & 90 & 8.001 & $\begin{array}{l}\text { Active client participation in reporting, problem-solving, and improvement relating to } \\
\text { the asset management service. }\end{array}$ \\
\hline $5 g$ & & 6.143 & 0.5 & 95 & 8.67 & Mutual trust and respect between the service provider and client organisation. \\
\hline $6 e$ & & 6.107 & 0 & 81 & 9.332 & The ability to measure the asset management service quality and value creation. \\
\hline
\end{tabular}

Figure 7: Prioritised list of CSF for the case study

\subsubsection{Case study feedback}

Both the asset owner and the service provider agreed with the overall potential of DSMams in support of decision-making and prioritising focus areas to improve asset management services. The asset owner stated: "This will help many engineers when they set up an asset management service or similar operations", while the service provider said: "It should be incorporated in [asset management services] to ensure that the [service provider's] team is set up in the most suitable way." 
Were the results a true reflection of the current state of the asset management service? The asset owner responded: "I was amazed to see the results and how close both parties' results came out. Yes, I believe they are true reflective results." The service provider agreed: "As we have an excellent client/service provider relationship which correlates with the high scores in the matrix, I would deem the criteria to be a true reflection."

\begin{tabular}{|c|c|c|c|c|c|}
\hline CSF & \begin{tabular}{c|c|c|} 
Bench- \\
mark
\end{tabular} & $\begin{array}{l}\text { Consen- } \\
\text { sus Dif }-\end{array}$ & \begin{tabular}{|} 
Adherence \\
-
\end{tabular} & $\operatorname{Rank}^{*} \bar{\top}$ & Description \\
\hline $6 f$ & 6.214 & 1 & 80.75 & 2.4 & $\begin{array}{l}\text { A focused and continuous improvement process to improve the asset management service through } \\
\text { monitoring, analysis, and feedback. }\end{array}$ \\
\hline $1 c$ & 6.107 & 1 & 80.75 & 3.2 & $\begin{array}{l}\text { The technical knowledge, expertise, and capabilities of the service provider's client-facing team and } \\
\text { consultants. }\end{array}$ \\
\hline $1 d$ & 5.929 & 1.5 & 76 & 3.4 & $\begin{array}{l}\text { The availability of the most appropriate skilled resources to provide industry-specific asset } \\
\text { management service requirements. }\end{array}$ \\
\hline $5 c$ & 6.214 & 1 & 90 & 4 & $\begin{array}{l}\text { The management of mutual expectations between the service provider and client relating to the asset } \\
\text { management service. }\end{array}$ \\
\hline $5 j$ & 6.071 & 1 & 90 & 5.2 & $\begin{array}{l}\text { The use of performance measurements to monitor, control, and improve the asset management } \\
\text { service. }\end{array}$ \\
\hline $1 a$ & 6.036 & 1 & 90 & 5.4 & $\begin{array}{l}\text { A capable project (or key account) manager who manages the asset management service on behalf of } \\
\text { the service provider. }\end{array}$ \\
\hline $5 \mathrm{~h}$ & 5.964 & 1 & 90 & 5.8 & $\begin{array}{l}\text { Active client participation in reporting, problem-solving, and improvement relating to the asset } \\
\text { management service. }\end{array}$ \\
\hline $5 \mathrm{k}$ & 6.000 & 0.5 & 76.5 & 6 & $\begin{array}{l}\text { Proper priority setting of improvement actions, irrespective of whether it is service or value-add } \\
\text { related. }\end{array}$ \\
\hline $1 \mathrm{e}$ & 5.964 & 0.5 & 85.5 & 7.8 & $\begin{array}{l}\text { The service provider team's internal characteristics (e.g. service continuity when team members are } \\
\text { redeployed to other services, and handover between service phases, such as implementation to } \\
\text { operations). }\end{array}$ \\
\hline $5 f$ & 6.464 & 0.5 & 95 & 7.8 & Open and effective communication. \\
\hline $5 d$ & 6.214 & 0.5 & 95 & 8 & $\begin{array}{l}\text { The active management of the relationship between the service provider and the client organisation } \\
\text { personnel involved in the asset management service. }\end{array}$ \\
\hline $6 \mathrm{e}$ & 6.107 & 0 & 81 & 8.4 & The ability to measure the asset management service quality and value creation. \\
\hline $5 g$ & 6.143 & 0.5 & 95 & 8.6 & Mutual trust and respect between the service provider and client organisation. \\
\hline $1 \mathrm{f}$ & 5.929 & 0 & 100 & 13.4 & $\begin{array}{l}\text { The integrity of the leadership and delivery team of the service provider and the set of values to ensure } \\
\text { sustainability of the service. }\end{array}$ \\
\hline
\end{tabular}

Figure 8: Updated prioritised list of CSF

To validate DSMams retrospectively, the participants were asked whether they thought the asset management service and the partnership would have benefited from having access to DSMams at the beginning of the service. They replied: "Yes, they would. It took about 2-4 years to establish all of these CSF, but having this information I believe it would have shortened this period by at least half." "Thinking back definitely. If you reflect on rather serious times of conflict and disagreement it would have helped to have known which CSF were lacking and which not, to be able to prioritise ...."

\section{CONCLUSION}

A summary of the success factors for asset management services is presented. For an asset management service to be successful and beneficial to all its stakeholders, the asset owner and service provider need to work in partnership on various success factors during each of the phases of the asset management service life cycle. It is not as important to design the perfect asset management service as it is to select an appropriate partner, and to have effective control and monitoring processes in place to improve the asset management service continually.

The most important of all is to gain support for the asset management service from all the stakeholders during the implementation and commissioning phases of the asset management service. Continued and sustained commitment from the asset owner's senior management is non-negotiable to ensure asset management service success, especially during the initial contracting phase of the asset management service. During the ongoing operational services phase, open and effective communication between the asset owner and the service provider is also critical to the success of the asset management service. 


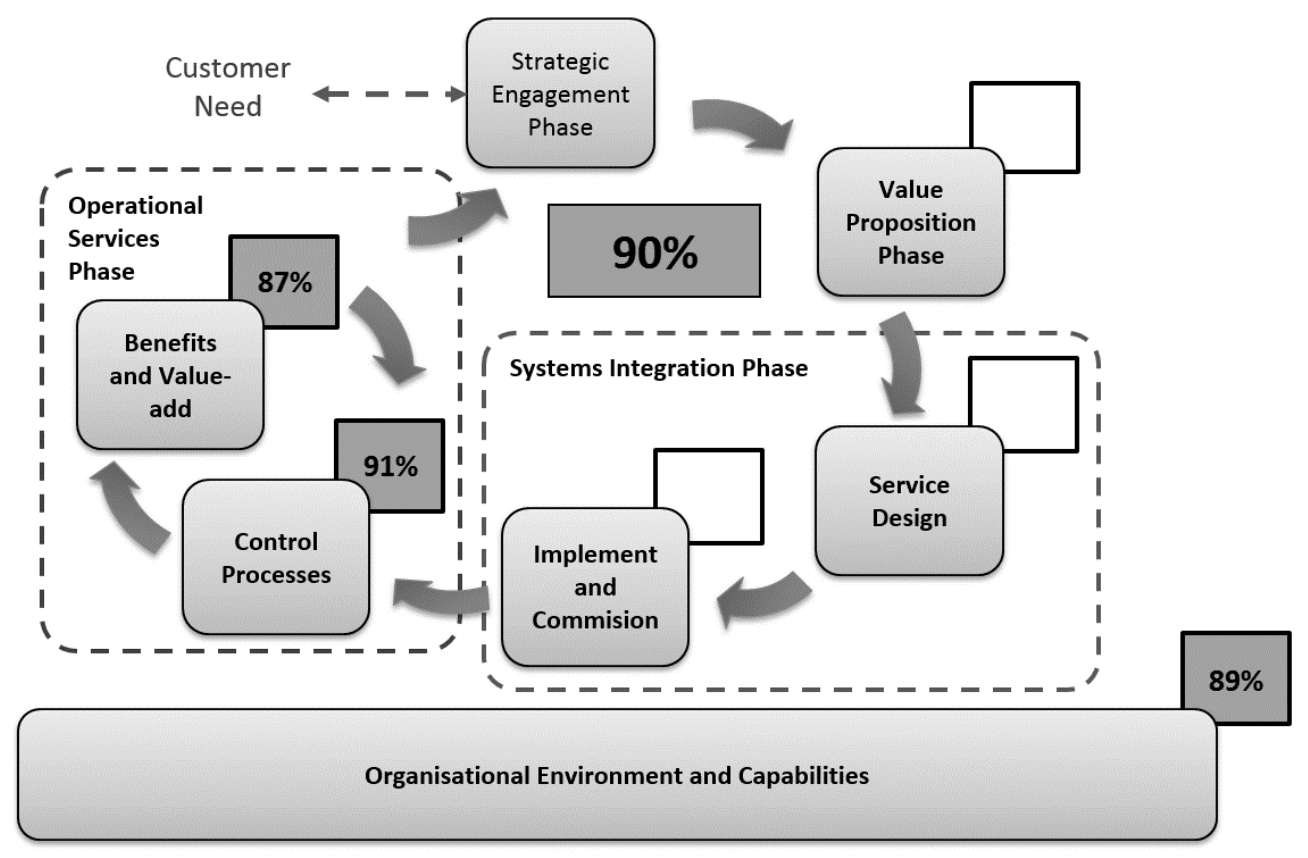

Figure 9: Benchmark compliance for the case study

With the exception of the two aforementioned CSF, the differences in importance between the remainder of the identified success factors for asset management services are not significant. Rather than just a select few CSF being important, all of the identified success factors for asset management services play an important role during specific phases of the asset management service life cycle. Ranking the success factors according to the industry benchmarks and the stakeholder assessments of adherence to the success factors makes it possible to prioritise the factors and to identify the CSF that asset owners and service providers should focus on in order to improve the service during a specific situation or phase.

A structured approach to providing asset owners and service providers with access to the CSF for asset management services is presented in the form of the DSMams. A case study of the practical application of the DSMams, with feedback from the participants attesting to its value to the asset management services industry, was presented. To gain the greatest benefit, the DSMams and the CSF for asset management services need to be incorporated as part of the contractual service-level agreement and operational processes of an asset management system.

Overall, this research contributes to the asset management body of knowledge by supporting the outsourcing requirements, as stated in PAS 55 and ISO 55000, with essential success factors that should be managed for a value-adding service relationship, and with a decision support model to facilitate improving these factors.

\section{REFERENCES}

[1] Amadi-Echendu, J. 2004. Managing physical assets is a paradigm shift from maintenance. In: IEEE International Engineering Management Conference Proceedings, pp. 1156-1160.

[2] Baines, T., Lightfoot, H., Benedettini, O. \& Kay, J. 2009. The servitization of manufacturing: A review of literature and reaction of future challenges. Journal of Manufacturing Technology Management, 20(2), pp 547-567.

[3] Bogan, C.E. 1994. Benchmarking for best practices: Winning through innovative adaptation, McGraw-Hill. 
[4] City of Cape Town 2014. Available at: http://www.capetown.gov.za/en/ achievementsandawards/Pages/AccoladesforCitysElecSupportServices.aspx, [accessed 10 July 2014].

[5] Cusumano, M. 2008. The changing software business: Moving from products to services. In: Proceedings of IEEE Computer Society, pp. 20-27.

[6] Gadiesh, O. \& Gilbert, J. 1998. Profit pools: A fresh look at strategy. Harvard Business Review, 76(2), pp 139-147.

[7] Grönroos, C. 2007. Service management and marketing: Customer management in service competition. $3^{\text {rd }}$ edition. John Wiley \& Sons: Chichester.

[8] Holmström, J., Brax, S. \& Ala-Risku, T. 2010. Comparing provider-client constellations of visibility-based service. Journal of Service Management, 21(5), pp 675-692.

[9] Hookham, J. 2010. What's the future for enterprise asset management? Available at: http://www.adrelia.com/doc/What's\%20the\%20Future.pdf [accessed 30 August 2011].

[10] International Standards Organisation. 2014b. BS ISO 55001:2014 Asset Management Management system - Requirements. The British Standards Institution.

[11] Jooste, J.L. and Vlok, P.J. 2014. Identifying the Critical Success Factors for Engineering Asset Management Services - An Empirical Study. In Proceedings of 2014 World Congress on Engineering Asset Management [accepted for publication]

[12] Leidecker, J.K. \& Bruno, A.V. 1984. Identifying and using critical success factors. Long Range Planning, 17(1), pp 23-32.

[13] Mitchell, J. 2002. Physical asset management handbook, $3^{\text {rd }}$ edition, Houston: Clarion Technical Publishers.

[14] Oliva, R. \& Kallenberg, R. 2003. Managing the transition from products to services. International Journal of Service Industry Management, 14(2), pp 160-172.

[15] Paquin, R. 2014. Asset management: The changing landscape of predictive maintenance. Technical Report, Aberdeen Group.

[16] Pragma 2010. Available at: http://www.pragmaworld.net/case-studies/html/ capetown.html [accessed 10 July 2014].

[17] Quinn, J., Doorley, T. \& Paquette, P. 1990. Beyond products: Services-based strategy. Harvard Business Review, 68(2), pp 58-67.

[18] Rockart, J.F. 1981. The rise of management computing. In A Primer on critical success factors, pp 1-75. Homewood.

[19] Schwab, K. 2013. The global competitiveness report 2012-2013. Technical Report, World Economic Forum.

[20] Vandermerwe, S. \& Rada, J. 1988. Servitization of business: Adding value by adding services. European Management Journal, 6(2), pp 314-324.

[21] Welch, B.L. 1947. The generalization of Student's problem when several different population variances are involved. Biometrika, 34, pp 28-35.

[22] Windahl, C. \& Lakemond, N. 2010. Integrated solutions from a service-centered perspective: Applicability and limitations in the capital goods industry. Industrial Marketing Management, 39, pp 1278-1290.

[23] Wise, R. \& Baumgartner, P. 1999. Go downstream: The new profit imperative in manufacturing. Harvard Business Review, 77(5), pp 133-141. 